\title{
The induction of maturation of female American eels through hormone injections*
}

\author{
R. K. EDEL \\ Graduate School of Oceanograpby, \\ University of Rhode Island, \\ Kingston, Rhode Island, USA
}

\begin{abstract}
KURZFASSUNG: Die Auslösung der Geschlechtsreife bei weiblichen amerikanischen Aalen durch Hormoninjektionen. Nach intramuskulärer Injektion von zerriebenen Karpfenhypophysen in $ㅇ$ von Anguilla rostrata gelang es, eine Keimzellenreifung bei 6 Blankaalen herbeizuführen. Die abgelegten Eier ähneln denen europäischer und japanischer Aale ( $A$. anguilla und A. japonica), die experimentell zur Geschlechtsreife gebracht worden waren. Die Eier sind rundlich und haben einen Durchmesser von $1 \mathrm{~mm}$. Da sie Oltropfen enthalten, scheinen sie pelagisch zu sein. Bei einem geschlechtsreifen ㅇ lag die Eizahl zwischen 1300000 und 1500000. Bemerkenswert ist das Auftreten eines stechenden Geruchs, der aus der Haut und dem Schleim geschlechtsreifer oder heranreifender weiblicher Exemplare entweicht. Die mögliche Bedeutung dieses Geruchsstoffes für das Auffinden der Geschlechtspartner während der pelagischen Laichphase wird diskutiert.
\end{abstract}

\section{INTRODUCTION}

This study was conducted to induce complete maturation in female American eels (Anguilla rostrata, Le Sueur) through the injection of hormone preparations. The American eel is one of three northern temperate species (the remaining two are the European eel, $A$. anguilla L. and the Japanese eel, $A$. japonica Temminck \& Schlegel) that undergo extensive catadromous migrations to tropical, pelagic spawning areas. Because of the work of ScHMidr (1922) we know that these eels spawn away from continents and at depths of from 50 to $500 \mathrm{~m}$. Since no ripe adult eels have been seen or caught while in the spawning area, we know little of their physiology or behavior during the time of spawning. It is assumed that eel eggs are pelagic. The induction of complete maturation in the laboratory is one feasible method for studying the biology of mature eels.

Two earlier attempts to induce maturation in female American eels were not successful: Hansen (1939) tried using frog pituitaries and chorionic gonadotropins, and BoEtrus et al. (1962) tried using human chorionic gonadotropin.

* This paper will be submitted in partial fulfillment for the degree Doctor of Philosophy in Oceanography at the University of Rhode Island. 
The first successful induction of maturation in the male Angwilla was reported by Boucher et al. (1935) and in the female by Fontaine et al. (1964) for the European eel. They obtained one mature specimen which spontaneously emitted eggs in the aquarium after three months of being injected with acetone-dried, powdered carp pituitaries. Olivereau \& Fontanne (1966) easily duplicated the achievement so the procedure of using carp pituitaries to induce maturation in eels was established.

Very recently, several Japanese investigators have been successful in inducing maturation in female Japanese eels. Ochiar et al. $(1972,1974)$ and Yamamoto et al. (1974a, 1974b) obtained ripe females by injecting them with salmon pituitaries or a purified fish gonadotropin called Synahorin. Yamamoto \& Yamauch (1974) followed this up spectacularly with in vitro fertilization and hatching of larval Japanese eels.

\section{MATERIALS AND METHODS}

Large female eels were purchased from a local fisherman in the late summer of 1973 and 1974. The eels were caught in baited pots placed in Ninigret Pond, Charlestown, Rhode Island, USA. The specimens were selected according to their size and condition. In 1973 both yellow and silver eels were selected as I wanted to determine whether hypophysation (the injection of dissolved fish pituitaries) would force yellow eels to metamorphose into silver eels as well as induce the maturation of female silver eels. In 1974 only female silver eels and eels clearly in an advanced stage of the silvering process were used. These latter eels were characterized by the loss of yellow pigment in their ventral surface, metallic gleaming along the flanks and the appearance of a milky-blue color in the axil of the pectoral fin. The eels were held in live cars for 2-5 days before the experiments were begun; they were not fed for the duration of the experiment. Each eel was placed individually into an 80-liter-tank of fiberglassreinforced plastic covered with hardware cloth to prevent escape. The tanks were contained in an isolated, windowless room which permitted the control of an artificial photoperiod and minimized disturbances. The eels were always held in sea water which was pumped into the research aquarium building from Narragansett Bay, Rhode Island. The sea water was flowing when the temperature was above $18^{\circ} \mathrm{C}$ but was shut off when the temperature fell below $15^{\circ} \mathrm{C}$. BoEtrus \& Boetrus (1967) showed that the temperature range for experimental maturation of male silver eels was about 11 to $25^{\circ} \mathrm{C}$ but was optimal at 18 to $22^{\circ} \mathrm{C}$ corresponding to depths from about $300 \mathrm{~m}$ to the surface for the winter months when eels probably spawn. The temperature within the tanks was continuously monitored by a Bristol Telethermometer placed in one of them. In 1973 the temperature ranged from 12 to $20^{\circ} \mathrm{C}$ (mean $19.5^{\circ} \mathrm{C}$ ) and in 1974 the temperature ranged from 14 to $24^{\circ} \mathrm{C}$ (mean $19.4^{\circ} \mathrm{C}$ ). The tanks were always aerated and periodic salinity determinations showed very little variation from $32 \%$. The artificial photoperiod was set at $12 \mathrm{~h}$ of $10^{3}$ lux at the water's surface (from 0600 to $1800 \mathrm{~h}$ ) and $12 \mathrm{~h}$ of total darkness (any night observations were made with a red bulb). The lamps used were daylight-simulating fluorescents which augment the blue end of the visible spectrum.

The hormones used were fish gonadotropic hormone (GTH) as contained in 
acetone-dried powdered carp pituitaries purchased from Stoller Fisheries, Spirit Lake, Iowa, USA, and luteinizing hormone (LH, specifically ovine NIH-LH-S18) donated by the National Institute of Arthritis and Metabolic Diseases, Bethesda, Maryland, USA. The powdered carp pituitaries were weighed, triturated and dissolved in $0.5 \mathrm{cc}$ of physiological saline per injection per animal. The LH required no trituration and was easily soluble in saline solution. The doses used were modified from FonTanNE et al. (1964) for the pituitaries and from FonTAINE \& GERARD (1963) for the purified LH. The pituitary dose was set at $10 \mathrm{mg}$ dry weight per eel per injection whereas the LH dose was set at $0.8 \mathrm{mg}$ per eel per injection.

The injection procedure was performed in the following manner. One eel was captured and placed into a polythene bucket containing an anesthetic solution (MS-222 in 1973 and Quinaldine in 1974) with $250 \mathrm{mg}$ of chloramphenicol, a broad spectrum antibiotic. When fully anesthetized, usually after 3 to $9 \mathrm{~min}$ of immersion, the fish was put onto a V-shaped trough and injected through a $2.5 \mathrm{~cm}, 20$ gauge needle intramuscularly (after BoEtrus et al., 1962) in alternate sides of the postvent dorsal muscle mass. Then the eel was photographed so that a serial record was maintained of any subtle external changes which occurred during treatment.

If an animal died naturally it was removed from its tank, photographed, weighed, and then dissected for the gonado-somatic index (GSI)* determination. Otherwise, the eels were individually removed from their tanks, anesthetised, weighed, photographed, dissected and the gonads photographed in situ.

\section{RESULTS}

The data obtained are presented in Table 1. In 1973 only one of the six eels injected with carp pituitaries showed any substantial increase in the GSI. That eel (experimental number 5) was one of two that had completely silvered prior to treatment. Gonadal enlargement became apparent in eel 5 after 7 injections (17 days) and continued until the eel was found dead on the 38th day. By that time she had been injected 16 times so a total dose of $160 \mathrm{mg}$ of carp pituitaries was administered to her. Free eggs were found in the tank but it was unknown whether they were extruded before or after death. The perianal region was swollen and the vent was enlarged to an oval about 15 by $20 \mathrm{~mm}$. Examination of the gonad showed eggs ranging in size from 0.59 to $1.25 \mathrm{~mm}$ but the mean diameter was $1.06 \mathrm{~mm}$ (Fig. 1). They were transparent and tended to be slightly ellipsoidal. Oil droplets were clearly visible. An aliquot sampling method gave estimates of 1.3 to $1.5 \times 10^{6}$ eggs. Morphologically the flanks became an intense copper color; the dorsal surface was dark but not black; the ventral surface which began as silvery-white became darkly mottled. The pectoral fins never became lanceolate and the eyes did not appear to enlarge. The caudal musculature was quite atrophied, a condition not sustained among the 5 remaining experimental eels and the 6 control eels starved for equal or longer times.

The remaining silver experimental eel (number 6) succumbed to vibriosis. No

* GSI $=$ gonad weight $\times 100 /$ whole body weight 
gonadal enlargement was detectable. The 4 experimentals which began as yellow eels seemed to be in the process of silvering but gonadal enlargement was only slight. The 2 silver control eels which were maintained for over 100 days in 1973 did show some gonadal enlargement. Their GSI's of about $6 \%$ are attributed to natural progression. The 4 yellow control eels showed no gonadal enlargement. They appeared to remain in the yellow form throughout the experiment.

In 1974 five of 6 experimental eels injected with dissolved carp pituitaries showed noticeable gonadal enlargement (Table 1). Eel 1 died of unknown causes on the 31 st day of the experiment and, while completely silver prior to treatment, showed no gonadal enlargement. After receiving 6 injections in 12 days, eel 5's gonads became

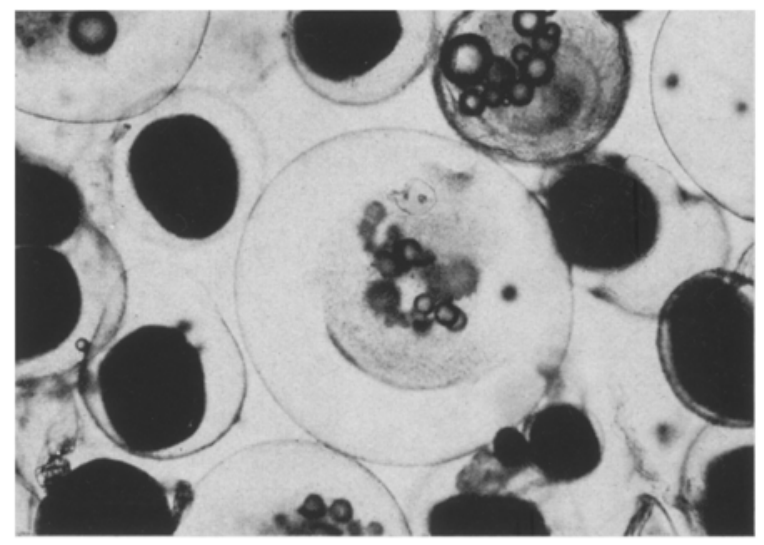

Figure 1: Whole eggs in sea water from eel 5, 1973. The large egg in the advanced stage measured $1.25 \mathrm{~mm}$ in greatest diameter. The smaller, less-advanced eggs (with dark yolks) measured $0.60 \mathrm{~mm}$ in greatest diameter. Oil droplets are visible in the yolk of the large egg

noticeably swollen. She progressed very similarly to her predecessor (eel 5 of 1973) but began extruding eggs on the $42 \mathrm{nd}$ day while still alive. Injections were discontinued at that time and her progress carefully monitored in order to see if there would be a climactic massive spawn or a steady rate of egg emission. Eight days after spontaneous egg emission began, eel 5 was discovered dead. Enough eggs remained in the gonad to give a GSI of 34.4. No egg count was deemed meaningful as so many were lost. The eggs were slightly smaller than those obtained in 1973 ranging in size from 0.50 to $0.99 \mathrm{~mm}$ (mean $0.78 \mathrm{~mm}$ ). Morphologically, eel 5 of 1974 was identical to eel 5 of 1973. A phenomenon which was largely ignored in 1973 became grossly apparent, however, in 1974. Both matured eels had a unique, pungent odor which seemed to emanate from the skin and mucus. Although it was detectable from the living eels, after death the odor was gone.

The 4 remaining carp pituitary-injected experimentals showed noticeable gonadal enlargement by the 30 th day of the experiment. None of them shed eggs, however, even though they received 3 injections more than eel 5 and were held at temperatures averaging $19.4^{\circ} \mathrm{C}$ for 103 days. The morphological characters approximated those of 


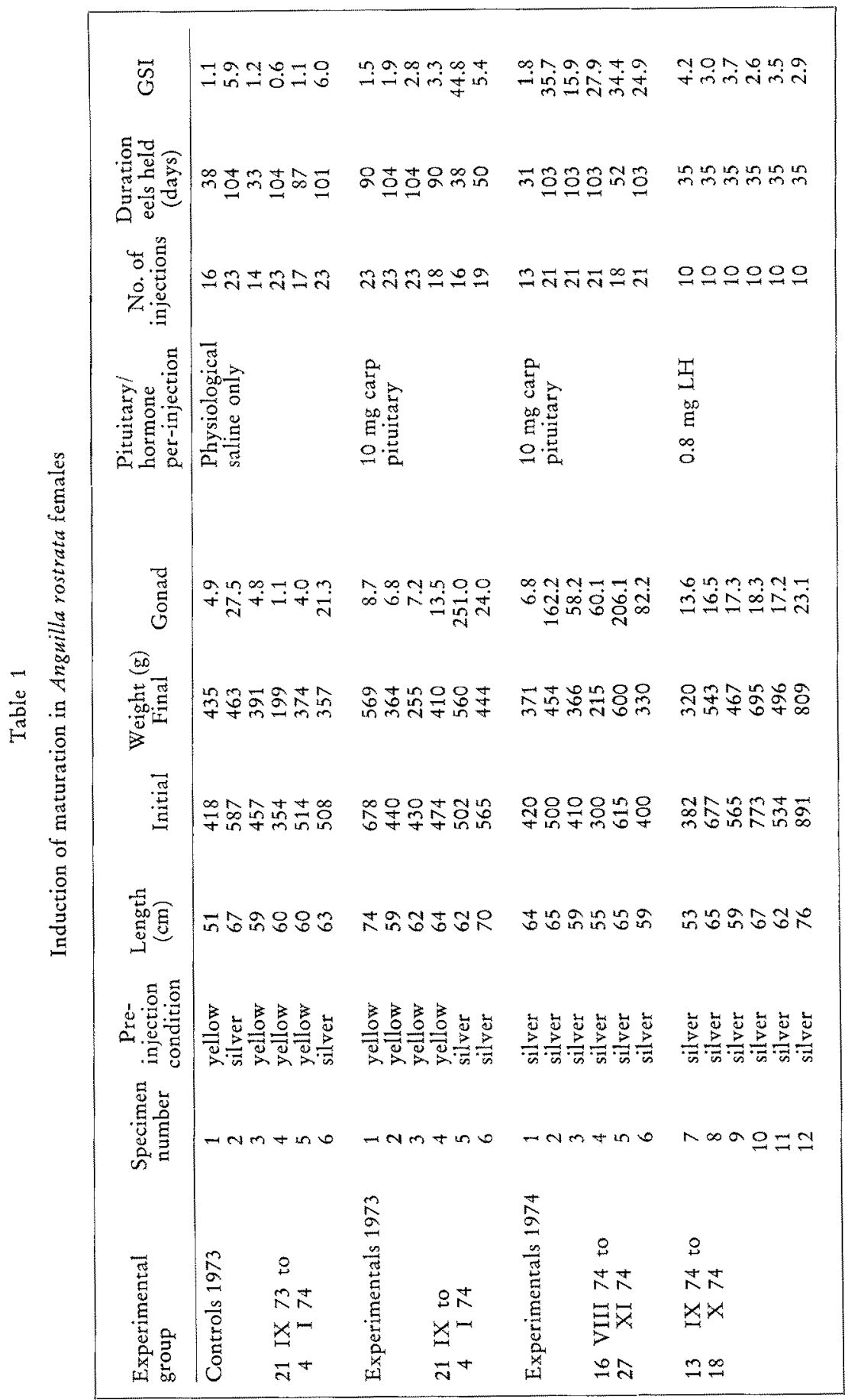


fully mature eels (including mottled ventral skin) and all gave off the unique "odor of ripeness". Atrophy of the caudal musculature was apparent in all 5 eels with advanced GSI's.

The 6 silver female eels which were injected with purified ovine LH showed no noticeable external or internal changes even though they were initially larger than the other 6 eels injected with pituitaries and treatment began later in the migratory season. They each received a total dose of $8 \mathrm{mg}$ (dry weight) of purified ovine $\mathrm{LH}$ which was determined by Fontaine \& Gerard (1963) to be equivalent in activity to $100 \mathrm{mg}$ of powdered carp pituitaries. The 6 GSI's which resulted were lower than those obtained from the 2 silver controls in 1973.

\section{DISCUSSION}

Female American eels can be induced into full maturity through the injection of powdered carp pituitaries. Two eels showed externally noticeable signs of oogenesis and incipient maturation after $2^{1 / 2}$ weeks of treatment. Both spontaneously emitted eggs in less than $11 / 2$ months which appeared to be of a size $(1 \mathrm{~mm})$ and state (migratory nucleus, see Ochiai et al., 1974 and Yамамото et al., 1974), indicative of maturity and fertilisability. These times were considerably shorter than those required to induce maturation in the European ( 3 months) or Japanese eel (as much as 6 months) indicating that the American eel is more mature when it emigrates than either of the other species. Since different hormone preparations and techniques were used by each investigator this comparison of times required for maturation is tentous. However, WENNER \& MUSICK (1974) reported finding migratory female silver eels in the Chesapeake Bay with mean egg diameters greater than those of American eels from Newfoundland waters or European eels from Danish waters. At this writing the cause of death of both matured eels is unknown but is probably related to the treatment and consequent maturation. A complete histological report is planned for the future.

The number of eggs contained in eel 5 of $1973,1.3$ to $1.5 \times 10^{6}$, is in agreement with the results of WENNER \& MUSICK (1974). For an eel the length and weight of eel 5, they found total fecundity to be between 1.3 and $2.0 \times 10^{6}$ although their specimens had a mean GSI of only $4.81 \%$.

It is not clear why 4 of the carp pituitary-injected experimental eels of 1974 never seemed to fully mature. All displayed noticeable gonadal enlargement and the morphological characters of the fully mature specimen but they appeared to advance only to a certain point and then no further. Declining sea-water temperatures may have been partly responsible. Furthermore, the injections were terminated about 40 days before the eels were sacrificied so some resorption is possible. Perhaps when the stimulating gonadotropins are withdrawn, the eels no longer use their skeletal musculature as an energy source for oogenesis but preserve it instead for the search for the spawning area or potential spawning partners.

The purified ovine LH was not efficacious in stimulating oogenesis in female American eels but the small dose and short experimental duration preclude statements on the usefulness and compatability of this hormone. Ovine LH was effective in 
stimulating gonadal activity in frogs (FonTAINe \& GERARD, 1963) but discordant results have been reported in fish (Burzawa-Gerard \& Fontaine, 1972). Further studies are needed.

One of the most interesting aspects of this study was the unique "odor of ripeness" given off by the two fully matured eels and the 4 partially matured eels. The odor was the same for the 6 eels mentioned but uniquely different from any others handled. The fact that the odor seemed to emanate from the skin and mucus leads to the suggestion that it may be an attractant useful to the eels in their pelagic spawning area for orientation or maintenance of aggregations. Further studies are needed to demonstrate and quantify this hypothesis.

\section{SUMMARY}

1. Female American eels (Anguilla rostrata LE SUEUR) were induced to mature by injecting silver migratory forms with powdered carp pituitaries.

2. The eggs of mature American eels resemble closely those of the European and Japanese eels, i. e. they are small $(1 \mathrm{~mm})$, almost spherical and have oil droplets within; thus, they appear to be pelagic.

3. The number of eggs of one mature specimen was in the range 1.3 to $1.5 \times 10^{6}$.

4. Purified ovine LH was not an efficacious gonadal stimulant in female American eels.

5. A unique and pungent odor detectable from the skin and mucus of matured and partially matured eels is described for the first time.

Acknowledgements. The author was supported by an Office of Naval Research grant to Professor H. E. WInN. I thank the National Institute for Arthritis and Metabolic Diseases for donating the ovine $\mathrm{LH}$ and Profs. H. WINN and D. PRATT for reviewing the manuscript. Dr. H.-P. BulnheIm kindly translated the abstract.

\section{LITERATURE CITED}

Boetius, I. \& Boetius, J., 1967. Studies in the European eel, Anguilla anguilla (L.). Experi. mental induction of the male sexual cycle, its relation to temperature and other factors. Meddr Danm. Fisk.-og Havunders. 4, 339-405.

Boetius, J., Boetius, I., Hemmingsen, A. M., Brunn, A. \& Møller-Christensen, E., 1962. Studies of ovarial growth induced by hormone injection in the European and American eel (Anguilla anguilla L. and Anguilla rostrata LeSueur). Meddr Danm. Fisk.-og Havunders. 3, 183-198.

Bovcher, S., Boucher, M. \& Fontaine, M., 1935. Sur la maturation provoquée des organes génitaux de l'anguille. C. r. Séanc. Soc. Biol. 116, 1284-1286.

Burzawa-Gerard, E. \& Fontaine, Y. A., 1972. The gonadotropins of lower vertebrates. Gen. comp. Endocrinol. 3, 715-728.

Fontaine, Y. A. \& Gerard, E., 1963. Endocrinologie comparée. - Purification d'un facteur gonadotrope de l'hypophyse d'un téléostéen la carpe (Cyprinus carpio L.). C. r. hebd. Séanc. Acad. Sci., Paris 256, 5634-5637.

Fontaine, M. M., Bertrand, E., Lopez, E. \& Callamand, O., 1964. Sur la maturation des 
organes genitaux de l'anguille femelle (Anguilla anguilla L.) et l'émission spontanée des oeufs en aquarium. C. r. hebd. Séanc. Acad. Sci., Paris 295, 2907-2910.

HANSEN, I. B., 1939. The experimental hormonal stimulation of the reproductive organs of the common eel. Bull. Mt Desert Isl. biol. Lab. 3, 25-26.

Ochial, A., Umeda, S. \& OTA, H., 1972. On the eggs of Japanese eel and induction of maturation by hormone injection. Jap. J. Ichthyol. 19, 312-316.

- - - \& OGA $\mathrm{GA}$, M., 1974. On the asceleration of maturity of the catadromous female eel by hormone injection and changes in the liver and blood character. Bull. Jap. Soc. scient. Fish. 40, 43-50.

Olivereau, M. \& Fontaine, M., 1966. Etude cytologique de l'hypophyse de l'anguille femelle mure. C. r. Séanc. Soc. Biol. 160, 1374-1378.

Schmidt, J., 1922. The breeding places of the eel. Phil. Trans. R. Soc. 211, 179-208.

WenNer, C. A. \& Musick, J. A., 1974. Fecundity and gonad observations of the American eel, Anguilla rostrata, migrating from Chesapeake Bay, Virginia. J. Fish. Res. Bd Can. 31, 1387-1391.

Yamamoto, K. \& Yamauchi, K., 1974. Sexual maturation of Japanese eel and production of eel larvae in the aquarium. Nature, Lond. 251, 220-222.

- Morioka, T., Hiror, O. \& OMori, M., 1974a. Artificial maturation of female Japanese eels by the injection of salmonid pituitary. Bull. Jap. Soc. scient. Fish. 40, 1-7.

- Omori, M. \& Yamauchi, K., 1974b. Oogenesis of the Japanese eel. Bull. Jap. Soc. scient. Fish. 40, 9-15.

Author's address: R. K. EDEL

Graduate School of Oceanography

University of Rhode Island

Kingston, Rhode Island 02881

USA 